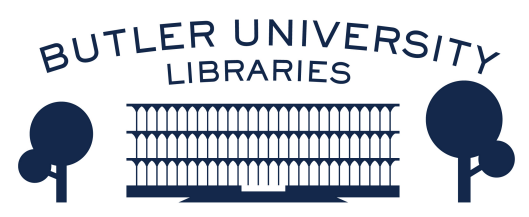

Journal of Hindu-Christian Studies

Volume 22

Article 16

January 2009

\title{
Book Review: "Beyond Compare: St. Francis de Sales and Sri Vedanta Desika on Loving Surrender to God"
}

Reid B. Locklin

Follow this and additional works at: https://digitalcommons.butler.edu/jhcs

Part of the Religion Commons

\section{Recommended Citation}

Locklin, Reid B. (2009) "Book Review: "Beyond Compare: St. Francis de Sales and Sri Vedanta Desika on Loving Surrender to God"," Journal of Hindu-Christian Studies: Vol. 22, Article 16.

Available at: https://doi.org/10.7825/2164-6279.1443

The Journal of Hindu-Christian Studies is a publication of the Society for Hindu-Christian Studies. The digital version is made available by Digital Commons @ Butler University. For questions about the Journal or the Society, please contact cbauman@butler.edu. For more information about Digital Commons @ Butler University, please contact digitalscholarship@butler.edu. 


\section{Beyond Compare: St. Francis de Sales and Sri Vedanta Desika on Loving Surrender to God. Francis X. Clooney, S.J., Washington, D.C., Georgetown University Press, 2008, $271+$ xiii pages.}

IN his preface and introduction Francis $X$. Clooney characterises this volume as the mature fruit of previous studies, including above all a 2008 commentary on the Tiru Mantra, Charama Shloka and Dvaya Mantra, also reviewed in this issue, and his Seeing through Texts a decade earlier, which won recognition as the "Best Book in Hindu-Christian Studies, 1994-1996." Beyond Compare does indeed extend and build helpfully upon these previous explorations of Shrivaishnava tradition, through a close comparative reading of two spiritual classics: the Treatise on the Love of God by the early modern Catholic bishop Francis de Sales and the Essence of the Auspicious Three Mysteries of the fourteenth-century Shrivaishnava teacher and commentator Vedanta Deshika. Yet it also feels far more preliminary than Clooney's earlier works, by design.

The focus of this comparison is, as the subtitle indicates, "loving surrender to God," a surrender that begins with reading and reasoning but can ultimately only bear its fruit in life beyond the text. In some contrast to Hindu God, Christian God (2001), Clooney does not uphold human reason here as the privileged bridge between and among different traditions; in fact, following the lead of Deshika and de Sales, he engages in a gentle polemic against ideals of pure reason, objectivity and any purportedly neutral reading of these texts. Scholarly detachment certainly holds an important place in Clooney's project, but only as means to a deeper goal of vulnerability and affective transformation, when the comparativist "gains the capacity to engage and respond to these traditions in a fuller way, with honesty regarding their potentially radical effects on how she lives" (208). In this respect, and in its comparative strategy of engaging in paradoxical "doublereading" of devotional texts, Beyond Compare reveals greater affinity with Clooney's treatment of goddess traditions and Marian piety in Divine Mother, Blessed Mother (2004). Here, the compared texts are more evenly balanced, the points of resonance more pronounced, and the imagined consequences more radical, if also for that very reason - remaining just outside our view.

At the core of Beyond Compare is a claim, borrowed from the aesthetic theorist Charles Altieri, that "manner matters," that imaginative literature transforms us not primarily "adjectivally," by directly introducing new values, ideas or courses of action, but "adverbally," by changing how we perceive our experience as a whole $(133-39,202)$. We can, thus, treat Clooney's work as in part an attempt to read Deshika's Essence Christian-ly. In chapter one, after introducing the two authors and their texts, Clooney recasts Deshika's practical, spiritual exegesis of three holy mantras in terms of de Sales no less practical, but more self-evidently affective desire that Christ might "animate my heart, and all hearts that shall read this writing" (21). "Then, in the next two chapters; he turns to questions: of authorial intent, the use and limits of reasoned discourse on the way to conversion, and strategic appeals to scripture and to heroic examples of holiness from past tradition to effect such conversion. It is telling that, though there is balanced alternation between both authors from one section to the next, it is de Sales that generally claims interpretive priority in these early chapters. The Catholic bishop writes in an idiom more familiar to most implied readers of Beyond Compare, and his vivid invocation of such holy models as John the Baptist, Catherine of Siena and Mary of Nazareth, for example, helps such readers enter imaginatively into Deshika's more formulaic citations of great teachers and lineages from Shrivaishnava tradition. By reading Deshika in conversation with a Christian classic like the Treatise, Clooney argues, it may be possible for a Roman Catholic to approach this Hindu tradition with a similar attitude of spiritual practice and even, beyond this, to become accountable to the 
distinctive demands of both traditions at one and the same time.

The goal of such a complex, interreligious reading does not, it seems, differ essentially from the goal of each text on its own terms: namely, surrender to a personal God. And, when Clooney takes up the question of surrender and its consequences in the life of faith more explicitly in chapters four and five, his focus subtly shifts from merely reading a Shrivaishnava text Christian-ly to imagining what it might be like to become the kind of Christian who gives herself Shrivaishnava-ly, in a manner deeply informed by the meditations and spiritual vision of Deshika's Essence. Most dramatically perhaps, after and out of Deshika's detailed exegesis of the Dvaya Mantra - "I approach for refuge the feet of Narayana with Shri; obeisance to Narayana with Shri" Clooney locates a comparable mantra in Jesus' own act of self-surrender - "Father, into your hands I commend my spirit" - which Christian believers can and must make their own. Clooney recognises stark differences between the two visions, to be sure: Deshika aims for exegetical precision, de Sales for death and resurrection, and both name the God to whom we must surrender with a specificity that does not permit combination or compromise. At some level, any attempt to bring them together will inevitably end in failure.

Yet Clooney makes the provocative claim that such failure, when it arises as a consequence of the sustained reading and reasoning modeled in Beyond Compare, will actually intensify the practice of both spiritual classics, separately and together. "Without the rhetoric of exclusivism and pluralism and without the comforts enjoyed by those who know only their own tradition or (seemingly). no tradition at all," he writes, "the reader . . . finds older habits and comforts no longer possible. Now unsettled by both texts, she or he comes closer to the precipice of a real act of loving surrender" (186). This claim is both beautiful and frustratingly asymptotic. In the conclusion, Clooney is back to comparison, describing Deshika and de Sales's respective accounts of life after loving surrender and reflecting briefly on the possibility of new persons and communities, Hindu and Christian, which might be effected through this kind of comparative study. Readers who have been waiting for him to advance a clear resolution or to take up some of those issues of truth he has "patiently deferred" in previous works will certainly find themselves rather annoyed at the end of this book, possibly to the point of giving up.

Indeed, writing as a devout Catholic, in a Shrivaishnava manner, this may be exactly Clooney's ambition.

Reid B. Locklin

St. Michael's College, University of Toronto

\section{The Experience of God: Icons of the Mystery. Raimon Panikkar. Translated by Joseph Cunneen. Minneapolis: Fortress Press, 2006, 148} pp.

EARLY on in this book Raimon Panikkar remarks on the paradoxical and indeed impossible nature of its title: we finite humans cannot by definition have an experience of God because God is not an object and certainly not an object of our finite discourse and experience. Nor can we, strictly speaking, talk of the experience of God in the subjective genitive, for, as Panikkar says, "There cannot be a genitive in God, for that would add nothing to what God is.
Even the verb to be is inappropriate" (p. 7). Panikkar embraces the paradox as both necessary and inevitable in the hope that awareness of this paradoxicality may relativize both our language and our conceptions of the Divine.

Two comments before launching into a discussion of the book and its contents. The book had its genesis in a series of seminars given to theology professors at the Benedictine 